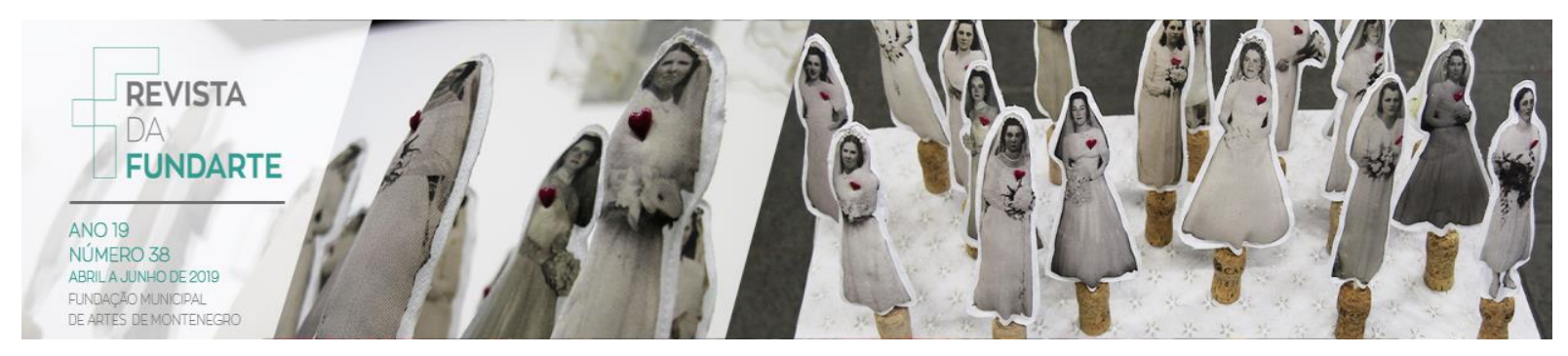

\title{
UMA BREVE HISTÓRIA DO DESENHO DA FIGURA HUMANA E SEUS CÂNONES
}

Anderson Luiz De Souza'

\begin{abstract}
Resumo: Desenhar a figura humana dita perfeita é um problema didático detectado em aulas de arte, onde alunos pedem "como desenhar uma figura humana perfeita". Ao buscar argumentos contra modos rígidos de representação, questiona-se a ideia de "corpos certos". Fazendo referência ao Cânone de Policleto, o artigo faz uma breve retomada histórica selecionando algumas referências da História da Arte ocidental para mostrar as mudanças sofridas na interpretação/representação da figura humana ao longo dos séculos. Pensar a figura de outra maneira é a finalidade desse artigo que investiga algumas particularidades relativas às variações dos cânones nas rupturas históricas da arte, as quais permitem descrever uma forma humana que não a canônica.
\end{abstract}

Palavras-chave: Figura Humana; Cânones; Desenho.

\section{A BRIEF HISTORY OF THE DESIGN OF THE HUMAN FIGURE AND ITS CANONS}

Abstract: Drawing the perfect human figure is a didactic problem detected in art classes, where students ask "how to draw a perfect human figure." In seeking arguments against rigid modes of representation, the idea of "right bodies" is questioned. Referring to Policleto's Canon, the article makes a brief historical resumption by selecting some references from Western Art History to show the changes in the interpretation / representation of the human figure over the centuries. To think of the figure in another way is the purpose of this article which investigates some peculiarities relative to the variations of the canons in the historical ruptures of the art, that allow to describe a human form that the canonical one.

Keywords: Human Figure; Canons; Drawing.

\section{Introdução:}

\begin{abstract}
${ }^{1}$ Mestre e Doutorando em Educação pelo Programa de Pós-Graduação em Educação - UFRGS, na linha de pesquisa Filosofias de Diferença e Educação (2015). Especialista em Arte Contemporânea e Ensino da Arte - ULBRA (2011). Graduado em Moda (Bacharelado) CESUMAR (2006) - Maringá/PR e Graduando em Artes Visuais (Licenciatura em andamento) UNIP. Professor Assistente da Universidade Feevale, lecionando no curso de bacharelado em Moda, no curso de Artes Visuais (bacharelado e licenciatura) e também no curso de Tecnologia em Design Gráfico, em disciplinas de desenho, processos de criação e computação gráfica. Ministra aulas em cursos de Pós-Graduação (Especialização) nas áreas da Arte, Moda, Design e Educação. Professor líder do projeto de extensão Espaço Cultural Feevale. Integrante do Processo C3 e membro do conselho editorial e colaborador do Informe C3 Periódico Eletrônico ISSN 2177-6954 (www.processoc3.com). Participa do grupo de pesquisa ARCOE: Arte, Corpo e EnSigno na linha de pesquisa Humores artísticos (UFRGS), integrando os projetos de pesquisa: Essa senhora: figuras femininas - incidências em Porto Alegre; Aparelhos disciplinares: poéticas, micropolítica, educação. Participante do projeto de extensão Estudos do Corpo (FACED-UFRGS). Performer e artista visual integrante do Coletivo M.A.L.H.A (Movimento Apaixonado pela Liberação de Humores Artísticos). Atuou como bailarino de dança contemporânea em festivais e mostras de dança. Desenvolve trabalhos como artista visual, figurinista, designer gráfico, ilustrador e fotógrafo experimental. Em suas pesquisas desenvolve temas que abordam processos de criação, o desenhar e o pensamento da diferença.
\end{abstract}

SOUZA, Anderson Luiz De. Uma breve história do desenho da figura humana e seus cânones. Revista da FUNDARTE, Montenegro, p.95-116, ano 19, no 38, abril/junho de 2019.

Disponível em: http://.seer.fundarte.rs.gov.br/index.php/RevistadaFundarte/index> 28 de junho de 2019. 


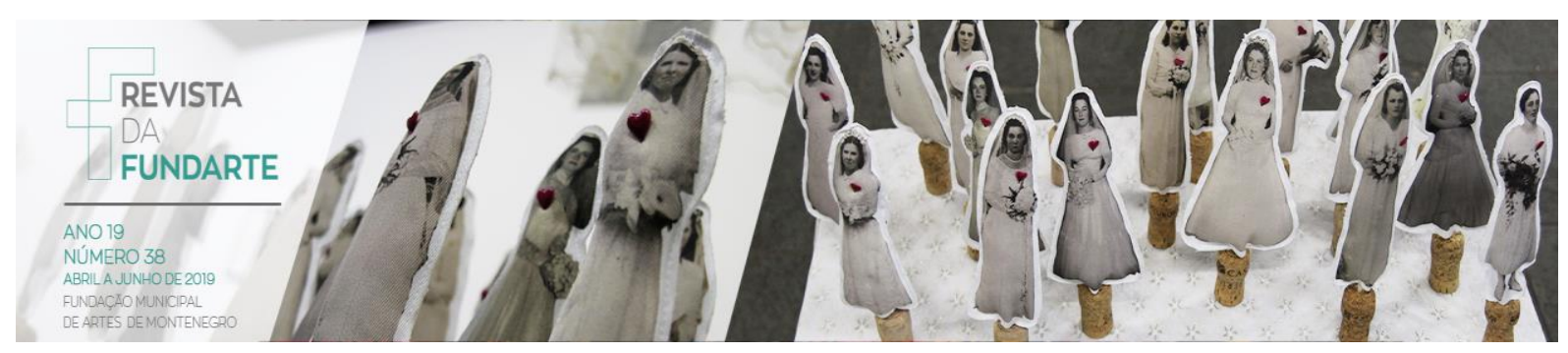

A partir de situações vividas em sala de aula em disciplinas artísticas na Educação Básica, em aulas de desenho de cursos de graduação nas áreas do Design e da Moda, em outras disciplinas em cursos de Artes Visuais e em aulas de especializações na área de Artes, detecta-se uma necessidade muito grande de se dominar a forma "correta" de representar a figura humana. A apropriação acadêmica dos modos canonizados de representação descreve totalizações reguladoras que mostram a preponderância de determinados tipos de visão sobre o desenho dessa figura.

Apesar do contexto observado ser brasileiro, o modo de olhar europeu ainda predomina sobre o que é "certo", sendo que um apanhado histórico sucinto procura responder à constante necessidade de se compreender essa quase "obsessão" contemporânea pela reprodução de um determinado tipo de corpo. Trata-se de um modelo que não corresponde ao que efetivamente existe no Brasil.

Essa representação de corpo ideal remete ao emblema do Deus Apolo, cujo classicismo moderno legou à Medicina e às Belas Artes. Especialmente no desenho da figura para croquis de moda, a forma de corpo apolíneo está referendada desde modelos de composição da antiguidade greco-romana. Os modos pelos quais a humanidade cria sua própria imagem variam de acordo com a época em que ela se pensa. O modo pelo qual o homem se vê, como representa a figura que ao mesmo tempo pode ser divina e ser o humano mesmo, imagem e semelhança, está impregnada na produção de seu lugar e de seu tempo. Trata-se de uma visão, panorama de uma época e um dado lugar (civilização greco-romana até os dias de hoje no Brasil), que mostra modos de se pensar como o humano se pinta, se molda, se desenha no devir das artes.

A produção aqui referendada compreende aquilo que pode ser intuído nas variações ocorridas em documentos visuais, tais como pintura, escultura, desenhos e iluminuras que apresentam novos modos de se trabalhar com o cânone nas contingências de cada contexto histórico. O pequeno levantamento feito aqui mostra uma maneira como, mesmo a composição que segue a medida dos cânones, contesta a própria tradição representativa onde os padrões detectados nela estão

SOUZA, Anderson Luiz De. Uma breve história do desenho da figura humana e seus cânones. Revista da FUNDARTE, Montenegro, p.95-116, ano 19, no 38, abril/junho de 2019.

Disponível em: http://.seer.fundarte.rs.gov.br/index.php/RevistadaFundarte/index> 28 de junho de 2019. 


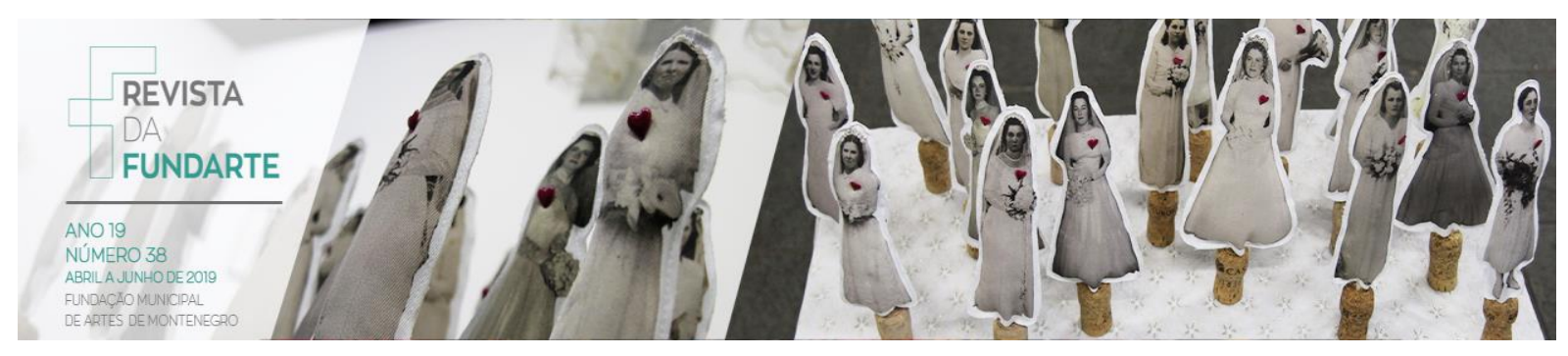

inseridos. O privilégio de um sistema de representação advém do que a historiografia compreende como cânone ou cânon, que nas tradições gráficas, pictóricas, plásticas e arquitetônicas esquematiza em padrões passíveis de procedimentos didáticos em prol de um resultado ideal.

\title{
A busca pela representação
}

A construção de uma composição visual dentro desses parâmetros, que visam atingir a "perfeição", são advindos de pesquisas específicas, especialmente aquelas desenvolvidas junto ao conceito de desenho, considerado a "base" para todo gênero de criações. De acordo com o historiador romano Plínio, o Velho, o qual faz apologia à descrição verbal tendo em vista a distorção ser própria das cópias visuais, o desenho tem origem atribuída ao traçado do contorno de uma figura humana. (BISMARK, 2014).

\begin{abstract}
Das muitas histórias contadas por Plínio existe uma, retomada por Alberti, sobre as origens míticas do desenho. A história passa-se em Corinto e conta que uma jovem, filha do ceramista Butades de Sicyone, apaixonada por um rapaz que teria de abandonar a cidade, desenha numa parede 0 contorno da sombra do seu amado, que a luz de uma lanterna projectava, guardando assim a memória da imagem dele. (RODRIGUES, 2000, p. 21).
\end{abstract}

Mesma lenda sobre o surgimento da pintura, ressalta-se que o mito da fixação de um contorno coloca a figura como elemento central nas criações visuais. Em sua definição, a palavra "figura" está ligada aos termos forma, aspecto, aparência, feitio, maneira, desenho, representação, entre outros. Em um dicionário do século XVIII, o verbete figura descrito como "forma externa, a feição de qualquer coisa (...) hum vulto com figura humana" (BLUTEAU, 1789, p.638-634). Deriva da palavra "fingere" que do latim tem sua tradução ligada a termos como supor, presumir, dar forma, pensar, etc. Para Deleuze, em seus estudos junto à pintura de Francis Bacon, a Figura pode ser um personagem, que quando submetida a procedimentos de isolamento, pode vir a se tornar "uma Imagem, um Ícone" (DELEUZE, 2007, p.12), que antes de ser um emblema é a forma sensível que se refere à sensação, a Figura vem a ser um corpo.

SOUZA, Anderson Luiz De. Uma breve história do desenho da figura humana e seus cânones. Revista da FUNDARTE, Montenegro, p.95-116, ano 19, no 38, abril/junho de 2019.

Disponível em: http://.seer.fundarte.rs.gov.br/index.php/RevistadaFundarte/index> 28 de junho de 2019. 


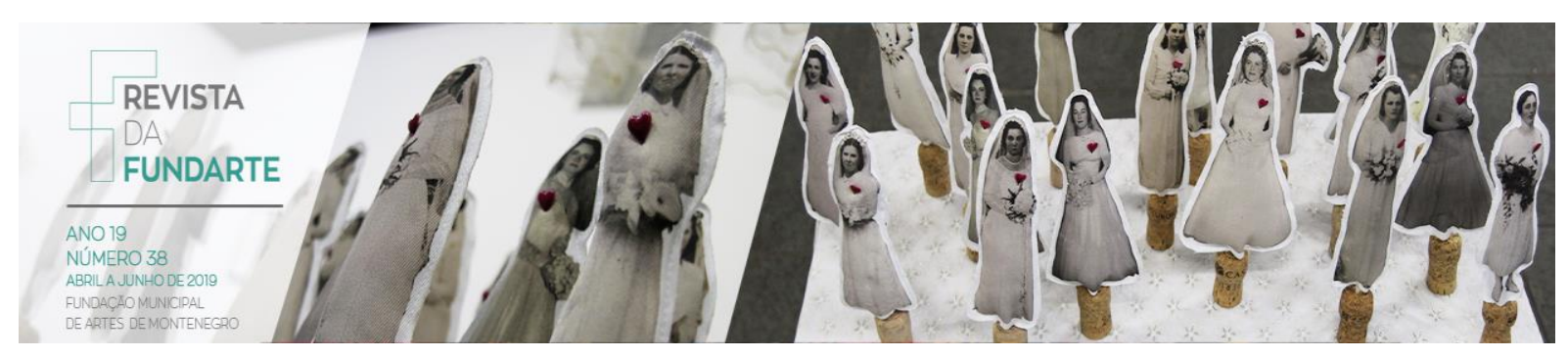

Por sua vez, a palavra "humana", que possui sua origem no latim humanus, designa o que é relativo ao homem. Ou seja, figura humana é aqui compreendida como aspecto do que é relativo ao humano, ou representação/desenho/suposição de algo que estabeleça relação a imagem anatômica de um ser humano. Ao citar Plínio, Ana Leonor Rodrigues localiza que dentro da tradição clássica "o desenho começou pelo corpo" (RODRIGUES, 2000, p. 21).A autora explica que por mais que a origem do desenho e da pintura possa vir a ser um tanto quanto obscura, não se pode afirmar com exatidão onde tenha sido inventada, se no Egito, na Grécia, em Sicion ou em Corinto.

Falar de desenho da figura humana é quase falar de representação. Ao se estabelecerem desde a Antiguidade, podendo ser situados desde a arte egípcia, os cânones foram objeto de estudos detalhados na Grécia. Da civilização grecoromana até o início do século XX (e ainda muito nos dias de hoje), a representação da figura humana passou a ser determinada por regras e tratados que ao longo do tempo foram sendo criados para definir modelos e verdades de como a figura humana deveria ser desenhada. Cânones que definem a representação do corpo humano por meio de estudos de proporção que "vinculam as partes do corpo à sua relação com o conjunto, com o corpo inteiro” (SARZI-RIBEIRO, 2007, p. 13). Dentro deste contexto Laneyrie-Dagen menciona que:

[...] a representação da figura humana foi a preocupação maior da arte ocidental e sua principal característica em relação às tradições artísticas judaica ou muçulmana. Mas os artistas, e depois deles os críticos, hesitaram entre dois partidos dificilmente conciliáveis: a busca da beleza ideal, isto é, da representação de um corpo humano perfeito [...], e a de uma verdade da representação, que dê a ilusão da presença de um personagem real. (LANEYRIE-DAGEN, 2004, p. 9.).

Os modelos e estudos de representação do corpo humano, que datam da Grécia antiga, partiam dos estudos da aparência humana e de certas proporções de partes do corpo. Alguns escultores, pintores e arquitetos, ao longo do tempo, foram criando seus modelos e definindo proporções e convenções tomadas como adequadas para a construção de uma figura humana dita "ideal e perfeita" para suas

SOUZA, Anderson Luiz De. Uma breve história do desenho da figura humana e seus cânones. Revista da FUNDARTE, Montenegro, p.95-116, ano 19, ํㅡ 38, abril/junho de 2019.

Disponível em: http://.seer.fundarte.rs.gov.br/index.php/RevistadaFundarte/index> 28 de junho de 2019. 


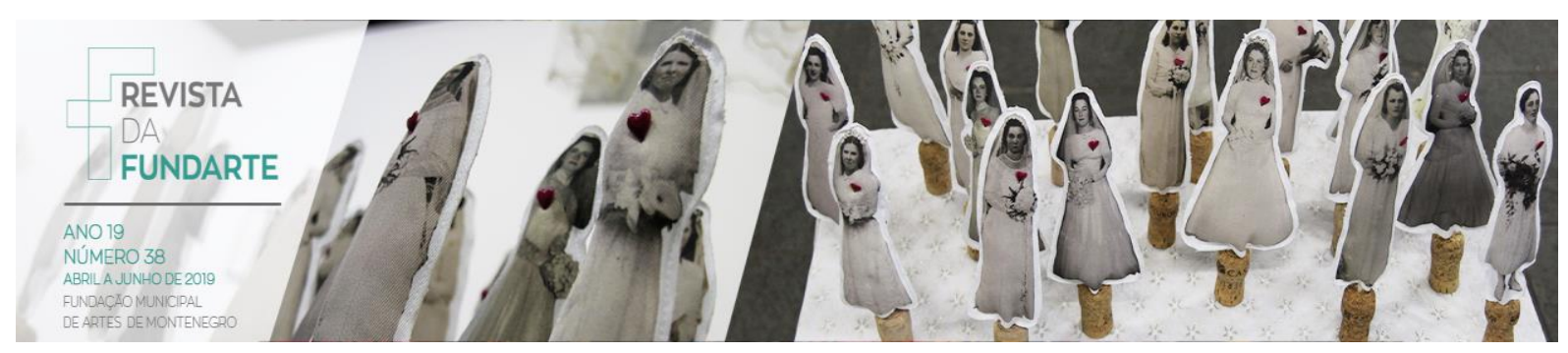

respectivas épocas. Preocupações que muito se assemelham aos discursos contemporâneos que se detêm na representação de corpos ideais esculpidos hoje por procedimentos cirúrgicos, atividades físicas, ou mesmo por softwares de edição de imagem, produzindo representações de modelos de corpos magros e longilíneos como as top-models.

\begin{abstract}
Essa noção foi desenvolvida pela produção e pelo discurso crítico de arte em contraposição ao corpo idealizado expresso no nu. Gênero artísticometafísico por excelência, o nu foi criado na Grécia em um momento no qual a própria imagem de corpo pôde ser pensada. Isso quer dizer que a concepção de corpo na cultura ocidental está intimamente ligada à questão da imagem e da representação. (MATESCO, 2009, p.7).
\end{abstract}

Muito do que se tem hoje como referência de representação da figura humana nas artes, devém da arte grega em seu período Clássico, entre os séculos V e IV a.C, marcado pelo governo de Péricles e pelas tragédias de Sófocles. Por mais que os gregos deste período ainda não tivessem "uma palavra para arte e talvez nenhum conceito de arte como uma categoria de objeto ou atividade distinta de algo feito com beleza ou habilidade" (BIRD, 2012, p. 97), o autor observa que havia a produção de formas humanas que conseguiam integrar observação e idealização, em conjunto com as habilidades técnicas que se faziam necessárias para compreendê-la. Somado ao legado cultural e religioso, no que se refere à filosofia, matemática e a ampla e rica narrativa mitológica, tais modos de representação se tornam cânones convencionalizados.

Cânone, palavra advinda do grego kanon, objeto que seria uma espécie de régua, expressa um conjunto de regras as quais funcionam como instrumento de medida o qual, trazendo modelos e convenções para estruturar determinados trabalhos técnicos, estabelece códigos específicos para composições visuais, musicais, arquitetônicas e classificação da importância de obras literárias. Nas artes plásticas e visuais os cânones clássicos, advindos da cultura greco-romana romperam limites territoriais e se espalharam por muitos continentes, regendo modos de fazer, desenhar e compor a figura humana.

SOUZA, Anderson Luiz De. Uma breve história do desenho da figura humana e seus cânones. Revista da FUNDARTE, Montenegro, p.95-116, ano 19, no 38, abril/junho de 2019.

Disponível em: http://.seer.fundarte.rs.gov.br/index.php/RevistadaFundarte/index> 28 de junho de 2019. 


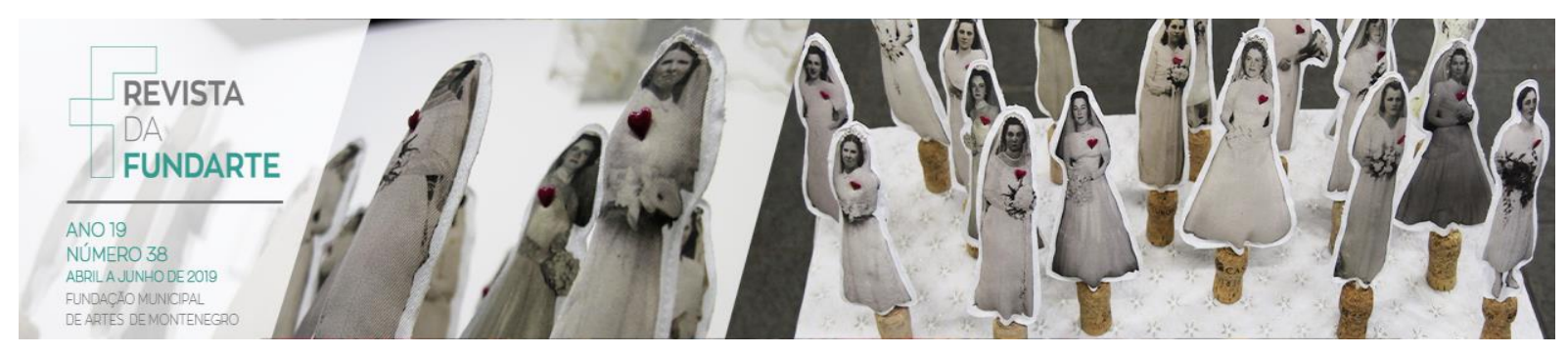

Tanto na Grécia quanto na Roma antiga, homens e deuses foram pintados e esculpidos de forma a representar a imagem de homens e mulheres. $E$ de acordo com os estudos de Margarida Calado, o ensino foi se dando entre a teoria descrita nos tratados e a prática do desenho. Sendo relevante destacar que, na Grécia deste período, a arte era considerada um trabalho manual (uma technê) sem grande prestígio, "e embora não haja grande conhecimento de como se transmitia a forma de pintar e desenhar, os próprios artistas preocupavam-se com a melhor forma de 'imitar a natureza'”. (CALADO, 2012, p.110).

Ao copiar muitas obras de origem grega e helenística, os romanos, deram continuidade às tradições gregas, mantendo como objetivo de sua arte a imitação da natureza (mimesis), embora expandindo os temas representados para as paisagens e motivos decorativos. Bird (2012) salienta o caráter "propagandístico" da arte romana, a qual reinventa a estética dos antecessores gregos a partir do viés pessoalista e estatal. São dos povos romanos os primeiros retratos e estátuas de personagens políticos que procuram reproduzir características físicas das pessoas representadas.

Um dos exemplos mais antigos da tradição canônica visual, ainda hoje utilizado, seja o criado pelo escultor Policleto de Argos, que por volta do século V a.C., escreveu um tratado intitulado o Cânon ou Cânone. O tratado consiste em um sistema de proporções que se estabelece entre uma unidade básica e o comprimento de várias partes do corpo. Para exemplificar sua teoria, Policleto criou em bronze uma estátua de Aquiles (também conhecida como "O Portador da Lança" ou ainda como o "Dorífero") com dimensão maior que a escala humana .(STOKSTAD, 2005).

Embora o tratado e a estátua original tenham sido perdidos, restaram cópias da estátua em pedra e mármore que foram produzidas por romanos algum tempo mais tarde. Philippe Comar, conta que deste tratado se conhece apenas a frase "A beleza é realizada pouco a pouco, através de muitos números" (, 1999, p.21). O que se sabe hoje sobre o tratado, dá-se com base nas produções e registros de contemporâneos a Policleto e de estudiosos que analisaram a fundo as cópias Revista da FUNDARTE, Montenegro, p.95-116, ano 19, no 38, abril/junho de 2019.

Disponível em: http://.seer.fundarte.rs.gov.br/index.php/RevistadaFundarte/index> 28 de junho de 2019. 


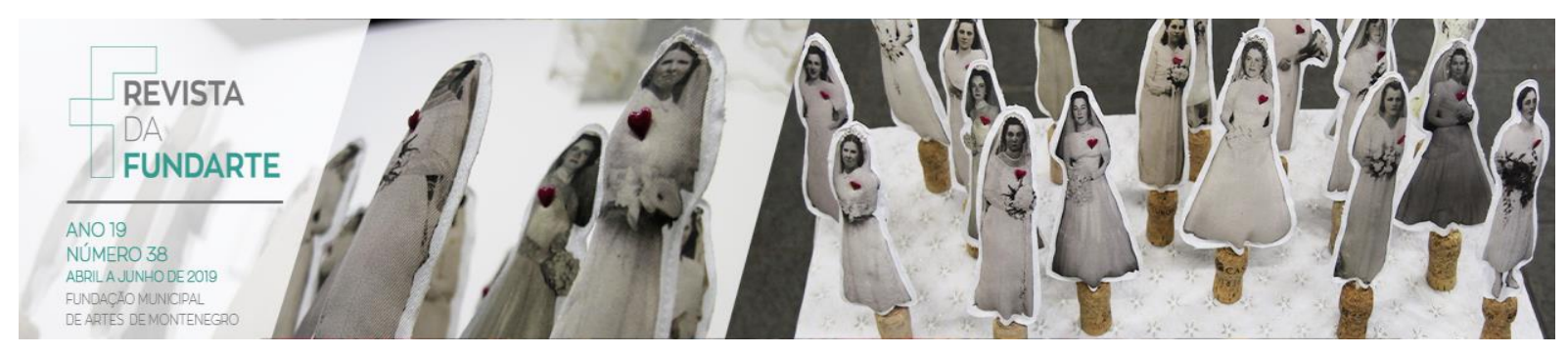

existentes da estátua de Aquiles na tentativa de se determinar a proporção ideal estabelecida por Policleto.

Como o tratado original não existe mais, todas as informações que se têm a seu respeito acabam se tornando suposições pautadas em interpretações de fontes incompletas. Tal impasse torna comum a existência de autores que defendem que a proporção ideal para se representar uma figura humana seria, segundo Policleto, a do cânone de sete cabeças (Figura 1), e autores que definem a mesma proporção como sendo a de sete cabeças e meia.
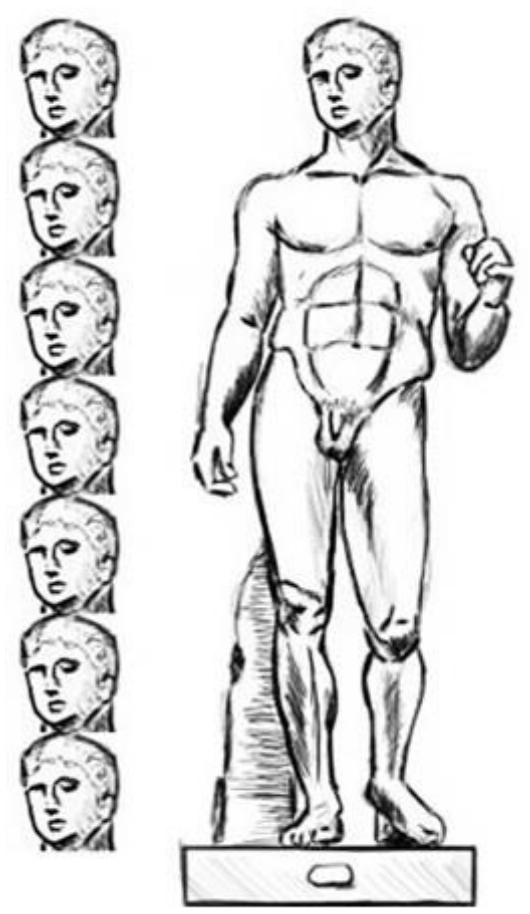

Figura 1 - "Dorífero" com representação da proporção de sete cabeças. Acervo pessoal, 2014.

Independentemente de qual tenha sido a proporção exata definida por Policleto, muitos outros pintores, escultores e estudiosos ao longo da história da humanidade foram estabelecendo diferentes cânones para a representação de figuras humanas produzidas como modelos ideais.

A Antiguidade legou-nos, portanto, uma prática de representação do corpo humano, pintado ou esculpido, normalmente idealizado, embora no período helenístico as representações se alarguem às diversas idades da vida, da

SOUZA, Anderson Luiz De. Uma breve história do desenho da figura humana e seus cânones. Revista da FUNDARTE, Montenegro, p.95-116, ano 19, oㅜ 38, abril/junho de 2019.

Disponível em: http://.seer.fundarte.rs.gov.br/index.php/RevistadaFundarte/index> 28 de junho de 2019. 


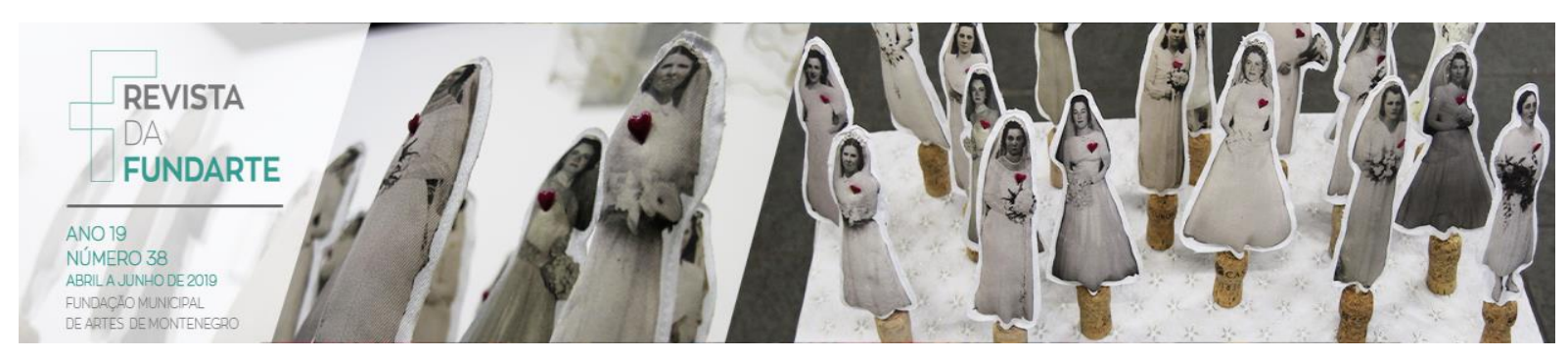

infância à velhice, e mesmo à deformidade física. Pela importância que deram ao retrato, os romanos continuaram a representação naturalista, embora a concepção idealizada permanecesse na representação dos deuses. (CALADO, 2012, p. 110-111).

Em sua pesquisa, Calado menciona que durante a Idade Média houve uma diminuição nos registros que apontavam o uso do desenho, e que esta constatação acabava por ter duas distintas hipóteses. A primeira apontava que a prática do desenho havia sido quase abandonada, se restringindo a esboços e rascunhos feitos a carvão ou pincel, antevendo a pintura de muros, afrescos e/ou mosaicos, assim como "esboços à pena no pergaminho para as miniaturas" (CALADO, 2012, p.111), que de qualquer maneira estavam fadados a desaparecer com a execução das obras por completo. E a segunda hipótese se fundamenta por autores que afirmam ter existido um desenho autônomo, que não era necessariamente subordinado à pintura, mesmo sendo raro encontrar nos dias de hoje algum destes registros.

Nesta época os objetivos da representação deixam de ser a imitação da natureza (mimesis), o que faz com que a preocupação com a tridimensionalidade expressa na representação de volumes e na composição e distribuição das figuras no espaço passem a dar lugar a uma imagem esquemática, simplificada e bidimensional observadas nos ícones bizantinos e iluminuras românicas.

$\mathrm{Na}$ Idade Média, "o desenho deixa de ter função estrutural e de suporte da representação e reduz-se a uma indicação sumária das formas, ao contorno e delimitação dos campos cromáticos." (CALADO, 2012, p.111). Durante o processo de restauro de mosaicos e afrescos, se encontrou na Itália registros de desenhos preparatórios (também conhecidos como sinópias). A maior parte desses registros datam da Alta Idade Média, embora, em razão da iconografia, sabemos que essas figuras eram reproduzidas por mais de cinco séculos.

Existem também desenhos medievais que reproduzem pinturas ou esculturas mais antigas e que servem como exemplo, para assegurar a continuidade da tradição, ou seja, a fidelidade iconográfica a modelos antigos, aos quais, como no caso das figuras de santos, se atribuía um valor de autenticidade histórica. (CALADO, 2012, p.111).

SOUZA, Anderson Luiz De. Uma breve história do desenho da figura humana e seus cânones. Revista da FUNDARTE, Montenegro, p.95-116, ano 19, no 38, abril/junho de 2019.

Disponível em: http://.seer.fundarte.rs.gov.br/index.php/RevistadaFundarte/index> 28 de junho de 2019. 


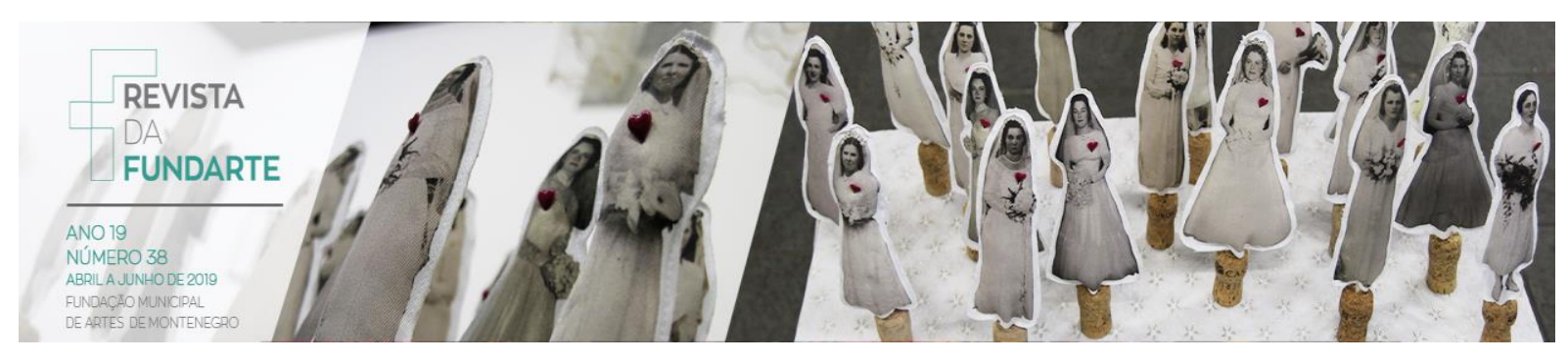

E foi na Idade Média também que se estabeleceu uma teoria das proporções que tomava como base o princípio da esquematização planimétrica.

\begin{abstract}
A teoria bizantina das proporções, de base clássica, elaborou um esquema tomando a articulação orgânica do corpo humano como ponto de partida, mas aplicou de forma algo rudimentar o sistema do módulo. As dimensões do corpo humano, na medida em que se projectavam num plano, exprimiram-se em "comprimentos de cabeça", ou mais exactamente de "rosto". O tamanho do corpo somava, em geral, nove destas unidades. Por exemplo, o Manual do pintor do Monte Athos atribui uma unidade ao rosto, três ao torso, duas tanto à parte superior como à parte inferior da perna, um terço da unidade, ou seja, o nariz, à parte superior da cabeça e ao pescoço. (PANOFSKY,1995, p. 91).
\end{abstract}

No século $X V$ acontece uma retomada dos modos de representação gregos, especificamente em Florença, Itália, quando artistas começaram a reintroduzir em seus trabalhos padrões pelos quais o empenho artístico passa a se mediado. Tendo o humanismo como força motriz caracterizado pela ordem, simetria, perspectiva linear, espaço, movimento e temas clássicos expressos tanto na arquitetura quanto em imagens de heróis e deuses mitológicos, assim como também nas pinturas advindas de histórias pagãs, este projeto era visto como ambicioso e paradoxal ao sintetizar valores clássicos com o cristianismo. (LITTLE, 2010).

No Renascimento, o sistema de medidas proposto por Vitrúvio, que no final do século I a.C estabelecia regras para se definir as medidas ideais dos corpos criados a partir da teoria das ordens arquitetônicas, veio a ser tomado como referência por muitos artistas como Leonardo da Vinci, Albrecht Dürer e Piero della Francesca.

Posteriormente, no que vem sendo conhecido como período Clássico, situado entre o estilo Barroco, o Rococó e o Neoclássico pré-romântico, Nicolas Poussin, Jean Dominique Ingres, Pier Paolo Rubens, entre tantos outros, utilizaram as regras e tratados propostos por seus antecessores e também propuseram seus próprios tratados e definições, propagando estilos de corpos de acordo com os contextos, os padrões e a estética da época. As diferentes formas de tratar a figura desses

SOUZA, Anderson Luiz De. Uma breve história do desenho da figura humana e seus cânones. Revista da FUNDARTE, Montenegro, p.95-116, ano 19, № 38, abril/junho de 2019.

Disponível em: http://.seer.fundarte.rs.gov.br/index.php/RevistadaFundarte/index> 28 de junho de 2019. 


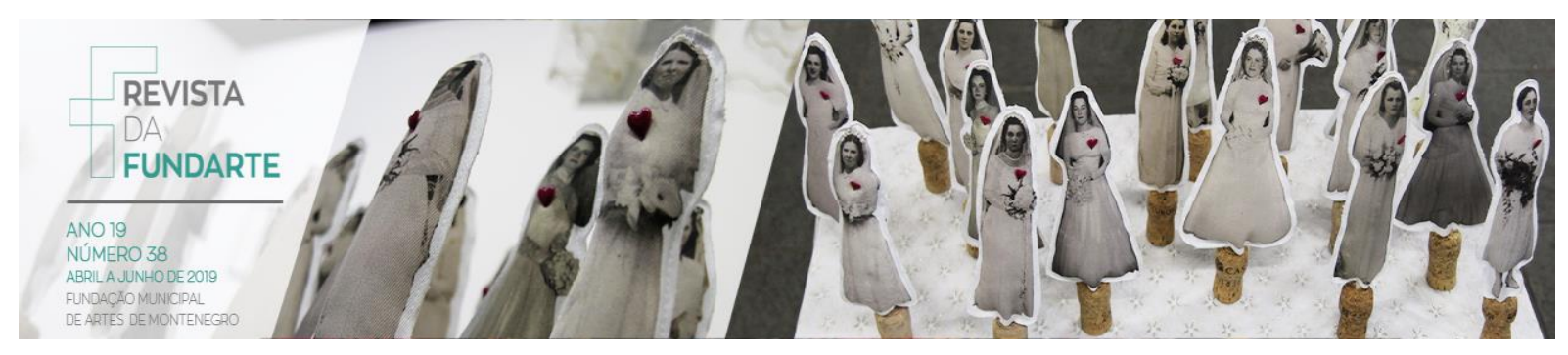

"mestres" evidenciam que não se tem um modelo fixo e tomado como verdadeiro para seguir, mas sim diferentes representações.

Com isso é possível pensar, também, que a representação da figura humana parte de anatomias diferentes que variam de acordo com condições étnico raciais, culturais, hábitos alimentares, condições de saúde, atividades físicas e outros fatores que constituirão o desenvolvimento anatômico de acordo com o local e o contexto de cada época. Assim pode-se pensar também nas diferenças de pessoas que nascem com deficiência ou de pessoas que adquirem alguma deficiência por meio de possíveis acidentes, ou seja, em corpos com "deformações" perante os cânones estabelecidos. Tal distinção canônica mostra uma diferença de ordem identitária, uma diferença que representa, que se dá por oposição, onde sempre se acredita que há um certo e um errado, sendo "certo" o modelo que o cânone estabeleceu.

Mesmo diante de todas as possibilidades e variáveis existentes para se representar o corpo humano em desenhos, pinturas ou esculturas, tanto em livros e publicações destinadas às mais variadas áreas do conhecimento, os cânones prevalecem até mesmo na confecção de figuras para histórias em quadrinhos e mangás. Observa-se que, em especial nos cursos destinados ao ensino do desenho, a estrutura dos desenhos de figuras humanas toma como fundamentação teórica as bases de cânones clássicos. Nestas, as proporções do corpo humano são definidas tomando a altura da cabeça como unidade de medida, a exemplo de Szunyoghy e Fehér (2010), os quais estabelecem que as proporções corretas da altura do corpo humano correspondem entre seis cabeças e meia a oito cabeças (Figura 2), sendo a medida de sete cabeças e meia a mais habitual.

SOUZA, Anderson Luiz De. Uma breve história do desenho da figura humana e seus cânones. Revista da FUNDARTE, Montenegro, p.95-116, ano 19, ํㅡ 38, abril/junho de 2019.

Disponível em: http://.seer.fundarte.rs.gov.br/index.php/RevistadaFundarte/index> 28 de junho de 2019. 

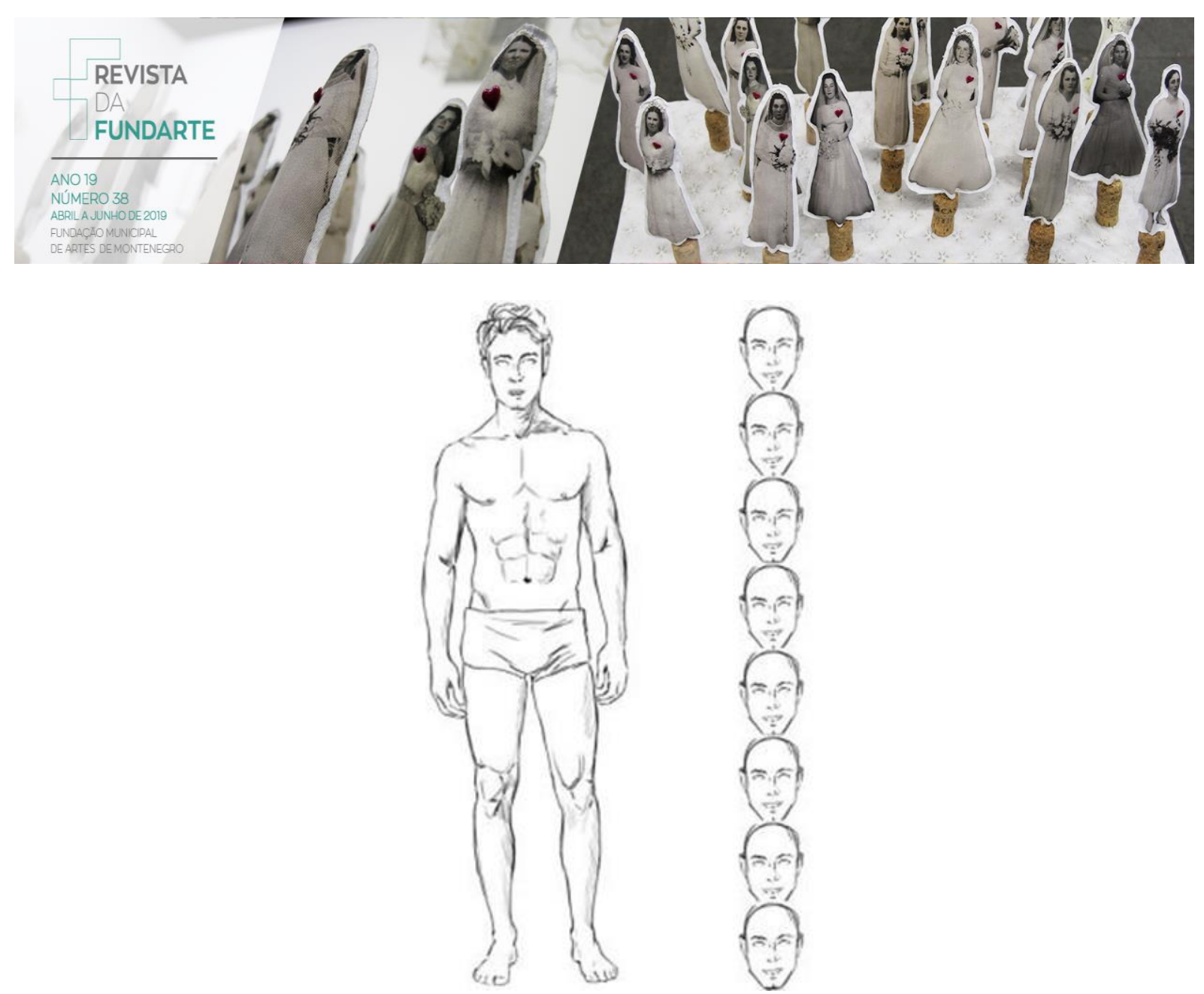

Figura 2 - Desenho de Figura humana representada com proporção de 8 cabeças a partir do exemplo proposto por Szunyoghy e Fehér (2010). Acervo pessoal, 2014.

Por muito tempo, vários dos modelos antigos de figuras humanas tidas como belas foram representadas nuas ou cobertas de forma simplória com panos soltos, de modo atemporal. Sendo que a partir do século XV, nomes como Sandro Botticelli (1445-1510), Rafael Sanzio (1483-1520), Johann Joachim Winckelmann (1717-1768), Jacques-Louis David (1748-1825), Jean-Auguste-Dominique Ingres (1780-1867), entre outros, que eram partidários desta tradição clássica a qual primava pela representação de anatomias ideais, passaram a manifestar em suas produções muito da nudez, ou quase nudez, que povoou a arte europeia desde então. (MARTINS, 2004,).

Segundo Laneyrie-Dagen, tal "orientação naturalista tomada pelas artes a partir do fim da Idade Média, leva até mesmo os pintores que defendem um belo ideal a refletir sobre os meios de dar carne e movimento a suas figuras." (2004, p.10). Para a autora, é fato que o século $X V$ inventou o corpo, ao investigar suas anatomias (com Leonardo da Vinci), assim como ao explorar "as condições de sua estabilidade e mobilidades de locomoção"(Ibidem) (com Alberti), e também, ao Revista da FUNDARTE, Montenegro, p.95-116, ano 19, no 38, abril/junho de 2019.

Disponível em: http://.seer.fundarte.rs.gov.br/index.php/RevistadaFundarte/index> 28 de junho de 2019. 


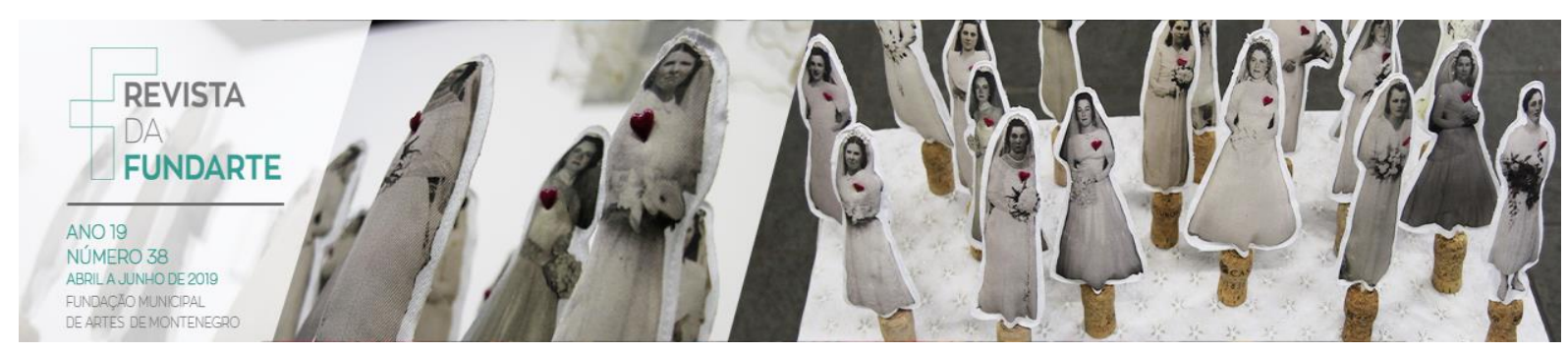

buscar maneiras de fazer ver, pelos gestos e a expressão, "as paixões dos diferentes personagens que a literatura teria exprimido por palavras" (Ibidem).

A "invenção" do corpo com bases em estudos anatômicos permite a criação de maneirismos em relação às figuras consagradas pelos grandes mestres do Renascimento, dando espaço para distorções e rupturas na construção canônica da figura, se fortalecendo com o desenvolvimento de estudos sobre a pantomima e a fisiognomia ou seja, a arte de julgar o caráter do homem, seu modo de sentir e de pensar, a partir de sua aparência visível, especialmente a partir dos traços fisionômicos. (ZAZIE, 2012, p.2). ${ }^{2}$

No século XVI, Giorgio Vasari vem a ser o primeiro a fazer uso do termo "maneirismo" para referenciar o estilo de pintura (e o movimento artístico) que, dentre tantas características, ao representar as figuras humanas, faz uso de "poses estranhas e o alongamento das figuras" (LITTLE, 2010, p. 38), atribuindo menos importância ao equilíbrio e a harmonia das composições, preferindo distorcer o que a Alta Renascença idealizava.

A partir do século XVII se propagam as Academias de Belas Artes, nas quais as disciplinas de desenho da figura humana, sob a égide dos tratados que ensinavam o cânone clássico, constituíam a base do currículo.

No século XVIII, auge do academicismo (o qual no Brasil somente no século seguinte começará a existir), o pensamento e a arte grega fundamentava parte de seus propósitos, visando ensinar a arte vista então como uma prática de busca intelectual, que era passível de ser ensinada de acordo com um sistema formal prédefinido.

Entretanto, ainda no século XVIII, a representação da figura humana passa por mais rupturas, pois, ao se cansarem de imitar as pinturas clássicas, alguns artistas deste período passam a criar novos modelos de corpos. Rompendo com muitos princípios vigentes desde o Renascimento, surgindo, por parte de alguns

2 ZAZIE. Fisiognomonia: Notas sobre a face, o carácter, a expressão das emoções e da sua aplicação nas ciências e nas artes. In h-Suplemento do Hoje Macau \#41 Suplemento h - Parte integrante da edição de 11 de Maio de 2012, ano XI, ํo 2607, p.2. Disponível em: http://issuu.com/hojemacau/docs/h-11-5-12. Acesso em: 10 mai. 2018.

SOUZA, Anderson Luiz De. Uma breve história do desenho da figura humana e seus cânones. Revista da FUNDARTE, Montenegro, p.95-116, ano 19, № 38, abril/junho de 2019.

Disponível em: http://.seer.fundarte.rs.gov.br/index.php/RevistadaFundarte/index> 28 de junho de 2019. 


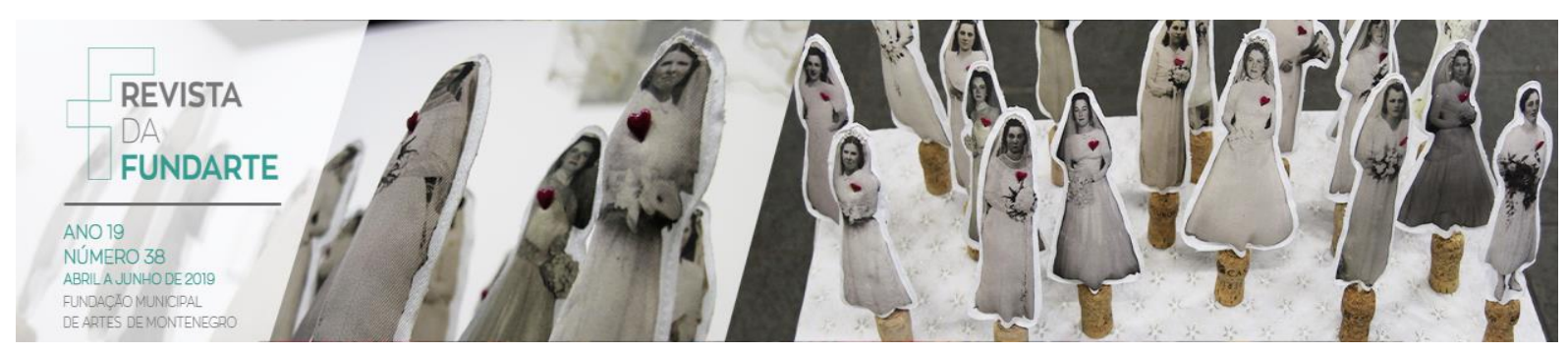

pintores e de acadêmicos que se valiam destes estudos, duras críticas ao sistema das proporções harmoniosas. Mas diante deste movimento de mudança, partidários do neoclassicismo, ainda defendiam com convicção os "caracteres essenciais do corpo figurado à maneira clássica" (LANEYRIE-DAGEN, 2004, p. 12), que ainda perdurou até meados do século XIX, assim como no trabalho de alguns artistas acadêmicos.

Mas os grandes pintores que, como Ingres, continuam a buscar sua inspiração em Poussin, e em Rafael e junto aos antigos, sentem-se divididos entre sua vontade de pintar a verdade, a modernidade de seu tempo e o imperativo de fundir esta última numa forma atemporal herdada dos antigos. (LANEYRIE-DAGEN, 2004, p. 12).

E é no decorrer do século XIX que a criação de novas possiblidades de representação da figura humana se formaliza. Artistas como Gauguin, vão buscar fora do ocidente referências para criação de novas imagens de corpos. Sendo que com o então advento da fotografia, a busca pela representação de um mundo com o mínimo de abstração ou distorção, herdado com o naturalismo, se torna desnecessária.

Na busca de escapar do realismo e do academismo, Cezanne e Degas, cada um à sua maneira, optaram por fazer uso de "uma nova definição de volumes ou desestabilizando, cortando - até chegarem a um corpo dividido em dois ou estirado no esforço da dança." (LANEYRIE-DAGEN, 2004, p.13). Assim como no exemplo de Courbet, que, em sua representação da figura humana, passou a abrir mão das noções de "bom gosto" “sacralizadas de 'próprio' ou 'impróprio'." (LITTLE, 2010, p. 81). No trabalho dos artistas deste período, a representação da figura humana, em especial na pintura, passa a aprender a se propagar abrindo mão de anatomias ideais.

No final do século XIX e nos primeiros anos do século $X X$, os pintores e os escultores reinventam assim um "novo" corpo que nada mais tem a ver com o cânone artístico tradicional, isto é, que não tende nem a dar a ilusão do natural, nem a refletir uma pretensa beleza ideal. O estatuto desse corpo, na arte, modifica-se consideravelmente a partir de então. (LANEYRIEDAGEN, 2004, p.13).

SOUZA, Anderson Luiz De. Uma breve história do desenho da figura humana e seus cânones. Revista da FUNDARTE, Montenegro, p.95-116, ano 19, nํ38, abril/junho de 2019.

Disponível em: http://.seer.fundarte.rs.gov.br/index.php/RevistadaFundarte/index> 28 de junho de 2019. 


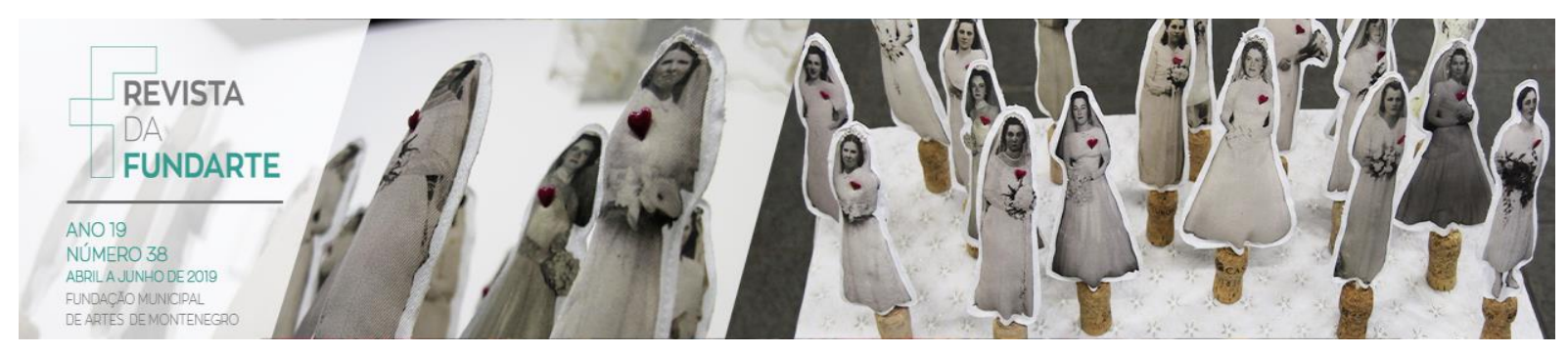

Com a invenção da abstração, os artistas que passam a utilizar mais de formas simbólicas do que de imagens que sejam fiéis a um modelo, passam a compor seus trabalhos com símbolos (não dogmáticos) que podem ser substituídos. E a representação da figura humana, assim como outras "formas suspeitas de reproduzir um objeto ou um elemento real" (LANEYRIE-DAGEN, 2004, p.13) dão espaço para outros modos de pensar a criação de novos corpos, que não sejam desenhados apenas de acordo com a preocupação clássica de representar uma ilusão perfeita, "terrorismo" de submissão a um modelo ideal.

Entre o fim do século XIX e meados do século $X X$, em um período que presenciou duas grandes Guerras, entre tantas outras revoltas e manifestações, a figura humana passou a ser pensada dentro de outros modos, outras maneiras de pensar sua representação. Apolo, o deus da forma perfeita, passa ao estatuto de "terrorista", como podemos ler na instalação de uma cabeça nos moldes clássicos de lan Hamilton Finlay. (Figura 03).

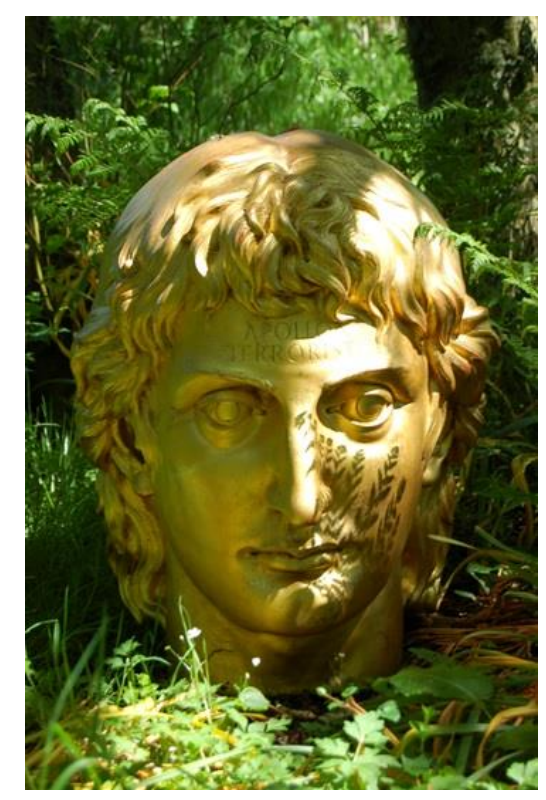

Figura 3 - Apolo Terrorista de lan Hamilton Finlay (1925-2006). ${ }^{3}$

\footnotetext{
${ }^{3}$ Ian Hamilton Finlay (1925-2006), Apollo Terrorista, Pequena Sparta Jardim de Esculturas, Dunsyre, Pentland Hills, Lanarkshire/Escócia/UK. foto de Tom Clark. Disponível em http://lookbyfranzkafka2.blogspot.com/2013/06/et-in-arcadia-ego-present-order-is.html. Acesso em: 10 out. 2018.
}

SOUZA, Anderson Luiz De. Uma breve história do desenho da figura humana e seus cânones. Revista da FUNDARTE, Montenegro, p.95-116, ano 19, no 38, abril/junho de 2019.

Disponível em: http://.seer.fundarte.rs.gov.br/index.php/RevistadaFundarte/index> 28 de junho de 2019. 


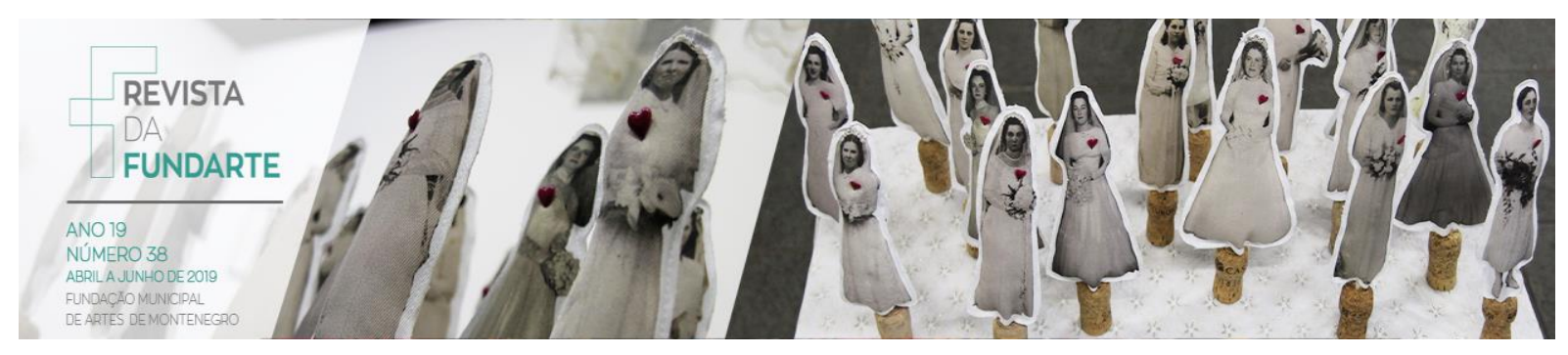

Muitos "artistas e escritores se voltaram para a criação de imagens do corpo dilacerado, dispostos a subverter a tradição do antropomorfismo." (CUNHA, 2011, p.165). Pois os modos de representar a figura humana, que nos séculos anteriores eram norteadas por padrões, organizados e estruturados de acordo com modelos de verdade que apontavam, muitas vezes, para essências, a partir do final do século XIX, passam a afastar-se dos modelos tradicionais. Assim, "às imagens ideais do homem veio contrapor-se um imaginário do dilaceramento, marcado pela obstinada intenção de alterar a forma humana a fim de lançá-la aos limites de sua desfiguração." (MORAES, 2012, p.19).

A exemplo das figuras pintadas pelo irlandês Francis Bacon, que não são representações do que se vê, "mas uma deformação propositada, que faz ver o que não se vê." (TADEU, 2012, p.12) A figura, em Bacon, se move pelos domínios da sensação, e segundo Deleuze, "a Figura não é apenas o corpo isolado, mas o corpo deformado que escapa.” (DELEUZE, 2007, p. 26).

\section{Quando as figuras escapam}

A busca por uma verdade no desenhar, por um desenho perfeito, o pensamento de que o desenho "bom" está diretamente ligado a uma verdade idealizada, tem se tornado problemático especialmente no que se refere a idealização do belo em relação à figura humana. $E$ tais questionamentos passaram a se tornar problemas ainda maiores quando questões similares se tornam recorrentes quando desenhar, para muitos aprendizes, se torna uma ação extremamente complexa e desagradável.

Saber desenhar uma figura dentro dos padrões clássicos de reprodução fiel à anatomia pode se tornar uma ação violenta, que causa incômodo. Em nossa prática como docentes em cursos de Artes, percebemos que tal violência decorre do fato de o aluno se colocar na condição de tentar representar uma imagem apolínea tomada como ideal, que a cada traço, a cada linha, a cada ponto mais se distancia de seu modelo, não conseguindo reproduzir de forma idêntica toda a complexidade dos detalhes que poderiam vir a compor tal desenho. E ao se deparar com uma figura

SOUZA, Anderson Luiz De. Uma breve história do desenho da figura humana e seus cânones. Revista da FUNDARTE, Montenegro, p.95-116, ano 19, ํㅡ 38, abril/junho de 2019.

Disponível em: http://.seer.fundarte.rs.gov.br/index.php/RevistadaFundarte/index> 28 de junho de 2019. 


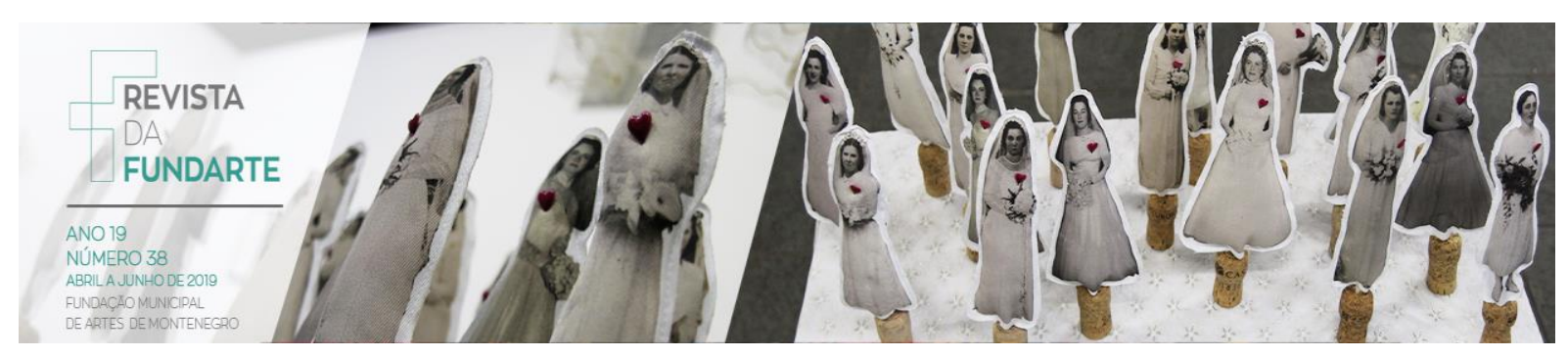

que nada, ou pouco, apresenta semelhanças com o modelo ideal, acaba sendo comum uma sensação de frustração e desistência em desenhar a figura, conforme Miriam Celeste Martins (1992) observou:

\begin{abstract}
Álibi para omissões, fracos resultados, o "não sei desenhar" acaba levando a que se pense que é "natural", isto é, que é da natureza humana que algumas pessoas não tenham condições de desenhar. (...) Se a criança, o jovem, o adulto dizem: "não sei desenhar" é porque acreditam que existem conceitos e regras que envolvem o Desenho e que eles não podem atingir, isto é, acreditam que existe um "desenhar direito" que impede a atividade artística (...) (MARTINS, 1992, p. 16).
\end{abstract}

Embora no decorrer do tempo as noções e modos de representação da figura humana tenham sempre se alterado, todos estes modos ainda são potentes hoje ao se pensar o ensino do desenhar, dentro dos mais variados campos da educação. Por mais que muitas destas teorias e tratados, que versam sobre os modos de como uma figura humana deva ser desenhada possam vir a ser consideradas antiquadas ou supérfluas, para alguns que trabalham com o desenho da figura humana, dentro do ensino superior e em cursos específicos, tais assuntos podem vir a se tornar tópicos produtivos para compor novos modos de pensar o ensinar e o criar no desenho da figura humana.

Experiências em desenhar os modelos canônicos sedimentam o desenhar dentro do terreno que define e localiza os desenhos como "ruins", ou mesmo como "maravilhosos" e que, toda arte moderna e as rupturas na representação da figura humana observadas desde o final do século $X I X$ até o século $X X$, mostra o quão obsoleta é a insistência na figura aos moldes clássicos. Todavia, para o senso comum a preferência pela proporção identificada ao corpo anatômico "saudável" ainda faz com que hajam aqueles que não se consideram capazes de desenhar junto aqueles que se consideram os detentores da "boa representação" localizando seus desenhos como os verdadeiros modelos de beleza e perfeição.

E para os que acreditam ter nascido sem o dom do desenho, pensando dentro de um registro estruturalista (SCHÖPKE, 2010), o conhecimento deverá

SOUZA, Anderson Luiz De. Uma breve história do desenho da figura humana e seus cânones. Revista da FUNDARTE, Montenegro, p.95-116, ano 19, no 38, abril/junho de 2019.

Disponível em: http://.seer.fundarte.rs.gov.br/index.php/RevistadaFundarte/index> 28 de junho de 2019. 


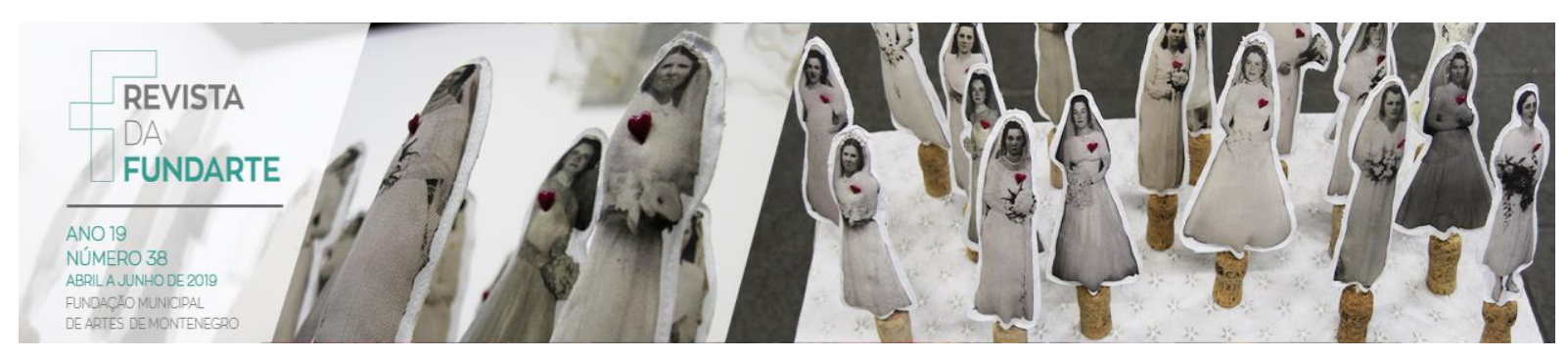

começar pela norma ${ }^{4}$, pois é com as normas que se irá definir o como desenhar, como segurar o lápis, como o papel deve ser usado, como observar o modelo, como apagar, como traçar, como finalizar. De acordo com este modo de pensar a norma é quem dá a segurança, determina como deve ser (forma e conteúdo), é quem afasta o medo de fazer errado pois, ao impor limites e restrições, o pensamento normativo direciona para "a verdade e o bem". O que torna o desenhar seguro e preciso, conduzindo o desenho, geralmente, para a representação de imagens dadas, soberanas e reconhecíveis.

E esta segurança que devém de normas, pode ser facilmente percebida no que tange o desenho de figuras humanas. Pois, por ser um motivo tão recorrente nas artes, e as imagens de corpo humano serem figuras com a quais nos deparamos por toda a vida, o desenhar de figuras humanas, no senso comum, está submerso em modelos, tratados, regras, normas, condutas que firmam dialeticamente como a representação dos corpos/figuras humanas devem ser, dentro de uma lógica anatômica e de uma racionalidade apolínea clássica.

Para mostrar as forças da ruptura canônica na arte moderna escolhemos uma artista brasileira cuja obra, ainda não catalogada, está centrada na figura humana. A pelotense Maria Lídia Magliani foge dos parâmetros masculinos e europeus, ainda que, por ser a primeira negra a concluir um curso de Artes no Rio Grande do Sul, tenha formação acadêmica calcada nos moldes do desenho de observação anatômico.

\footnotetext{
${ }^{4}$ Veiga-Neto e Lopes (2007), baseados em Ewald, afirmam que a norma, ao operar como uma medida e um princípio de comparabilidade, age no sentido de incluir todos, segundo determinados critérios que são construídos no interior e a partir dos grupos sociais. Para os autores, sempre de forma prescritiva, a norma age tanto na definição do modelo tomado a priori aos próprios sujeitos quanto na pluralização dos modelos que devem ser referência para que todos possam se posicionar dentro de limites locais, e uns em relação aos outros (LOPES; FABRIS, 2013. p.41-42). Estas autoras são trazidas para pensar a norma, e não para pensar a inclusão como é problematizado no respectivo livro.
}

SOUZA, Anderson Luiz De. Uma breve história do desenho da figura humana e seus cânones. Revista da FUNDARTE, Montenegro, p.95-116, ano 19, no 38, abril/junho de 2019.

Disponível em: http://.seer.fundarte.rs.gov.br/index.php/RevistadaFundarte/index> 28 de junho de 2019. 

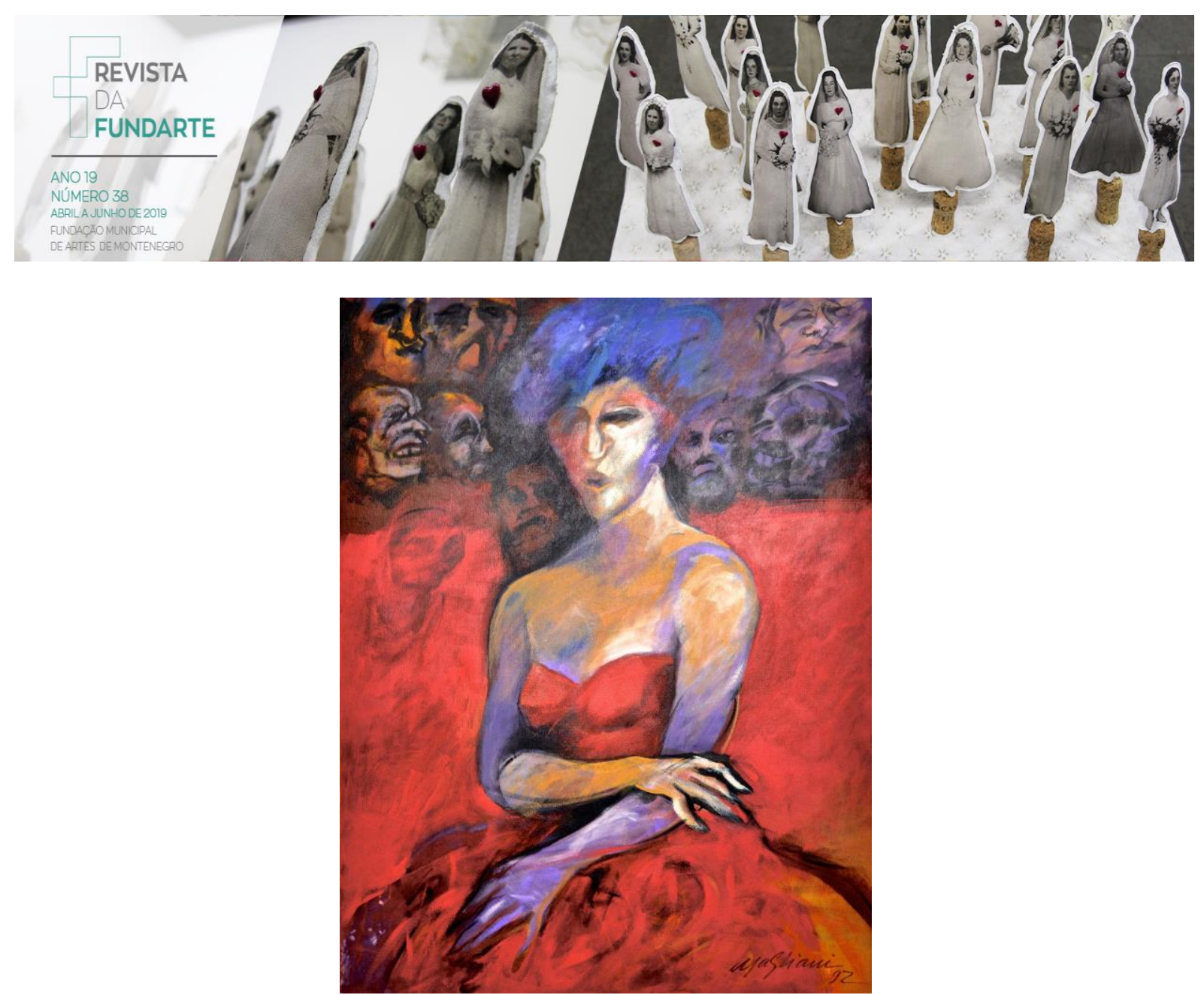

Figura 4 - Maria Lídia Magliani 1946 - 2012), Moça com Traje de Gala, acrílica sobre tela, $116 \times 89 \mathrm{~cm}, 1992 .^{5}$

O trabalho de Magliani mostra como a norma, a regra, a estrutura, assim como as linhas duras nem sempre podem ser tomadas como opressivas e perigosas, pois "cada linha tem suas promessas e riscos, sua necessidade e seus perigos." (PELBART, 2007, p. 285). Cada linha vem a compor sua parte, não sendo possível viver apenas com uma ou outra linha, pois todas atravessam a figura. E mesmo que a linha pareça ser a mais atraente em detrimento das demais, "nenhuma delas é "melhor" que as outras. Por mais que a linha de fuga pareça a mais "libertadora", ela também contém ameaças: pode conduzir ao desespero, à destruição, ao suicídio. " ((PELBART, 2007,, p. 286). Ao desenhar em meio a todas estas possibilidades de linhas que nos atravessam, se faz necessário uma delicadeza no manejo, ou, nas palavras de Deleuze, é necessário muito cuidado.

Logo, não se trata de negar as regras, as normas, as linhas duras, os modelos, as representações, os clichês, pois a criação se dá em meio aos cruzamentos e emaranhados de muitas linhas, tramas, redes e teias compostas por

\footnotetext{
${ }^{5}$ Disponível em https://www.blombo.com/pt/moca-com-traje-de-gala. Acesso em: 10 out. 2018.
}

SOUZA, Anderson Luiz De. Uma breve história do desenho da figura humana e seus cânones. Revista da FUNDARTE, Montenegro, p.95-116, ano 19, no 38, abril/junho de 2019.

Disponível em: http://.seer.fundarte.rs.gov.br/index.php/RevistadaFundarte/index> 28 de junho de 2019. 


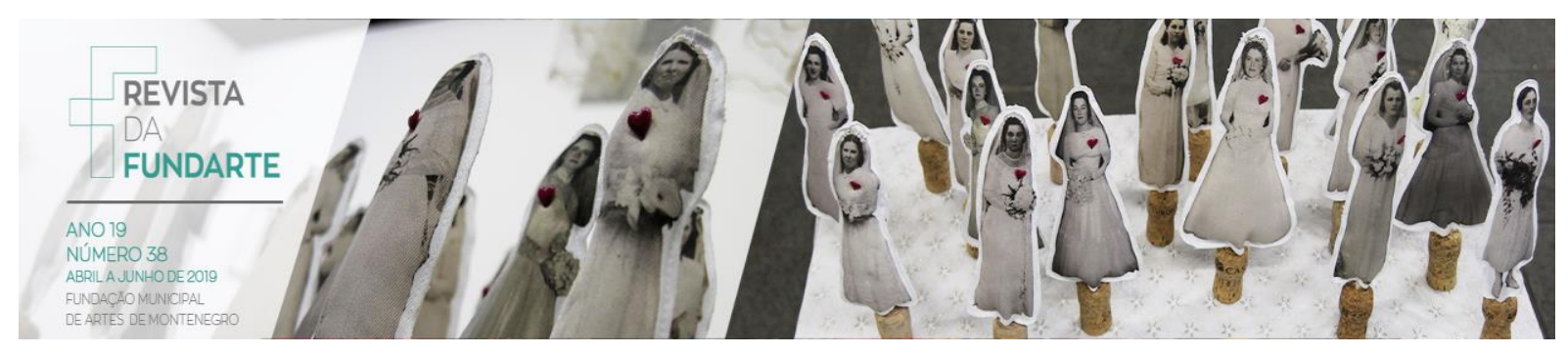

tais elementos. Mas, se as linhas duras estruturam e engessam o desenhar, conduzindo para a "representação como identidade, como mímese, como reflexo" (CORAZZA; TADEU, 2003, p.15.), para a busca de essencialismos, a constante variação dos cânones, mesmo quando mínima (em relação à meia cabeça na medida da figura) atesta a dificuldade de um enrijecimento totalizador. Mostrar que não há uma essência ideal na figuração do corpo, dando a ver o movimento das formas que parecem fixas, é o intuito desta investigação.

Uma breve retomada histórica dos modos de se figurar o humano em desenhos, pinturas, esculturas e outras produções artísticas ao longo dos séculos traz subsídios para se analisar como diferentes épocas e contextos pensam a própria humanidade. Aqui nos detemos na representação visual canonizada a fim de que possamos perceber como o modelo de figura tomada como ideal afeta noções do que é "certo" em torno do corpo humano. Sem desenvolver uma análise minuciosa sobre modos de olhar de acordo com determinadas contingências epistêmicas precisas, trouxemos linhas gerais para futuras investigações pormenorizadas. Estas envolvem toda a problemática conceitual sobre a representação da figura humana e o problema da representação frente às forças incorporais de obras de arte.

\section{Referências:}

BIRD, Michael. 100 ideias que mudaram a arte. São Paulo: Rosari, 2012.

BISMARK, Mário. Contornando a origem do desenho. In PSIAX, N. 3 (SÉRIE I) Estudos e reflexões sobre desenho e imagem. Porto: FBAUP, FAUP e EAUM publicações, $\quad$ p. 36-38, 2004. $\quad$ Disponível em: http://sigarra.up.pt/fbaup/pt/publs_pesquisa.FormView?P_ID=124. Acesso em: 12 maio. 2018.

BLUTEAU, Padre Raphael. SILVA, Antônio de Morais. Diccionrio da lingua portugueza composto pelo padre D. Rafael Bluteau, reformado, e accrescentado por Antonio de Moraes Silva natural do Rio de Janeiro (Volume 1: A - K). Lisboa: Na Officina de Simão Thaddeo Ferreira, 1789. 2 v., v. 1: xxii, p.638-634. Disponível em: http://www.brasiliana.usp.br/bbd/handle/1918/00299210\#page/432/mode/2up.

Acesso em: 08 abr. 2018.

SOUZA, Anderson Luiz De. Uma breve história do desenho da figura humana e seus cânones. Revista da FUNDARTE, Montenegro, p.95-116, ano 19, ํㅡ 38, abril/junho de 2019.

Disponível em: http://.seer.fundarte.rs.gov.br/index.php/RevistadaFundarte/index> 28 de junho de 2019. 


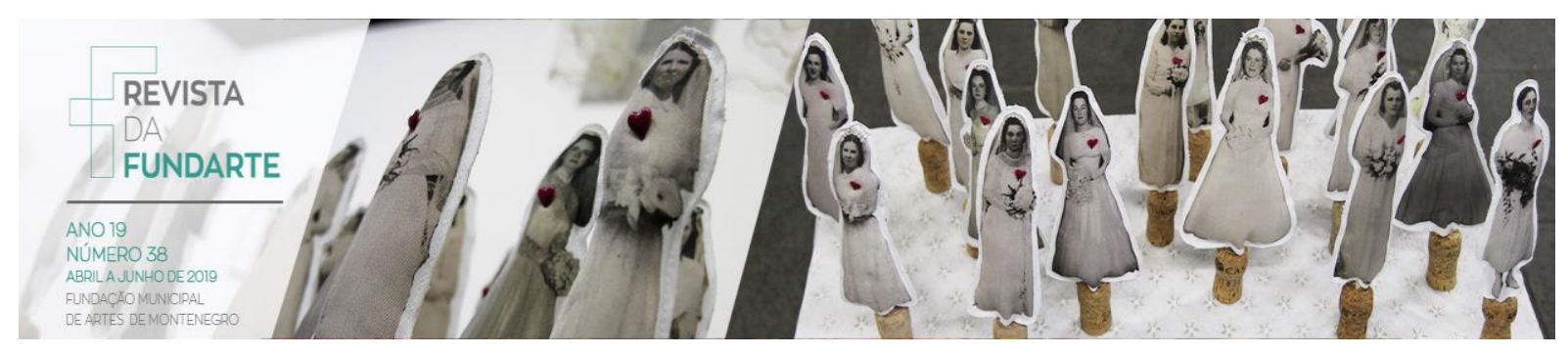

CALADO, Margarida. Desenhar o corpo-uma metodologia de ensino constante na arte ocidental. In TAVARES, Cristina Azevedo (Org.). Representações do corpo na ciência e na arte. Lisboa: Fim de Século, 2012.

COMAR, Philippe. The Human Body. Image and Emotion. London: Thames \& Hudson, 1999.

CORAZZA, Sandra; TADEU, Tomaz. Composições. Belo Horizonte: Autêntica, 2003.

CUNHA, Rubens da. A ruptura. A fragmentação. A impossibilidade. Resenha de $O$ corpo impossível de Eliane Robert Moraes. In: Revista Outra travessia: Revista de Pós-Graduação em Literatura, Dossiê Especial V. II: Psicanálise, Cinema e Literatura. Florianópolis: UFSC, 2011, p.165. Disponível em: https://periodicos.ufsc.br/index.php/Outra/article/view/2176-

8552.2011nesp2p165/22885. Acesso em: 02 mar. 2018.

DELEUZE, Gilles. Francis Bacon: A lógica da sensação. Rio de Janeiro: Jorge Zahar, 2007.

LANEYRIE-DAGEN, Nadeije. A figura humana. In LICHTENSTEIN, Jacqueline (Org.). A pintura: Vol. 6 A figura humana. São Paulo: Ed. 34, 2004.

LITTLE, Stephen. Ismos: para entender a arte. São Paulo: Globo, 2010.

LOPES, Maura Corcini; FABRIS, Eli Henn. Inclusão \& educação. Belo Horizonte: Autêntica Editora.

MARTINS, Fausto Sanches. O conceito de "Nihil Inhonestum" nos Tratados Artísticos Pós-tridentinos. In Estudos em Homenagem a Luís Antônio de Oliveira Ramos. Faculdade de Letras da Universidade do Porto, 2004. Disponível em: http://ler.letras.up.pt/uploads/ficheiros/5006.pdf_ . Acesso em: 01 ago. 2014.

MARTINS, Miriam Celeste Ferreira Dias. "Não sei Desenhar" Implicações no Desvelar/Ampliar do Desenho na Adolescência - uma pesquisa com adolescentes de São Paulo. São Paulo: Escola de Artes e Comunicação ECA/USP, 1992. 373 f. Dissertação (mestrado em artes), 373. p.16. Disponível em: https://www.academia.edu/6280268/_N\%C3\%83O_SEI_DESENHAR_. Acesso em: 07. Jun. 2014.

MATESCO, Viviane. Corpo, imagem e representação. Rio de Janeiro: Jorge Zahar Ed., 2009.

MORAES, Eliane R. O corpo impossível. São Paulo: lluminuras, 2012. p.19.

PANOFSKY, Erwin. El significado em las artes visuales. Madri: Alianza Forma, 1995.

SOUZA, Anderson Luiz De. Uma breve história do desenho da figura humana e seus cânones. Revista da FUNDARTE, Montenegro, p.95-116, ano 19, № 38, abril/junho de 2019.

Disponível em: http://.seer.fundarte.rs.gov.br/index.php/RevistadaFundarte/index> 28 de junho de 2019. 


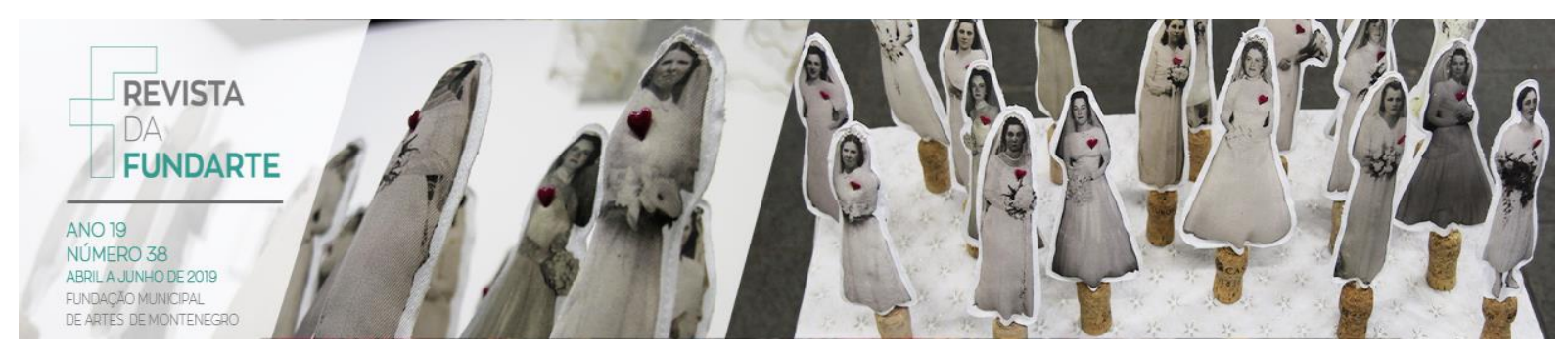

PELBART, Peter Pál. A arte de viver nas linhas. In DERDIYK, Edith (Org). Disegno. Desenho. Desígnio. 2. ed. São Paulo: Editora Senac São Paulo, 2007.

RODRIGUES, Ana Leonor Madeira. $O$ desenho. Ordem do Pensamento Arquitectónico. Lisboa: Editorial Estampa, 2000.

SARZI-RIBEIRO, Regilene Aparecida. A Figura Humana Fragmentada na Pintura: "Tiradentes esquartejado" em Pedro Américo e Adriana Varejão. 2007. $138 \mathrm{f}$. Dissertação (mestrado) - Universidade Estadual Paulista, Instituto de Artes de São Paulo, 2007. Disponível em: http://hdl.handle.net/11449/87008. Acesso em 01/08/2018.

STOKSTAD, Marilyn. Art History. 2 $2^{\mathrm{a}}$ edição revisada. New Jersey: Pearson education, Inc., 2005.

SCHÖPKE, Regina. Dicionário filosófico: conceitos fundamentais. São Paulo: Martins Martins Fontes, 2010.

SZUNYOGHY, András. FEHÉR, György. Curso de desenho anatômico: Ser humano. Potsdam, Alemanha: H.f.ullmann Publishing, 2010.

TADEU, Tomaz. Tinha horror a tudo que apequenava......In: Revista Educação: Especial Biblioteca do Professor, № 6. Deleuze Pensa a educação. São Paulo: Editora Segmento, 2012.

SOUZA, Anderson Luiz De. Uma breve história do desenho da figura humana e seus cânones. Revista da FUNDARTE, Montenegro, p.95-116, ano 19, no 38, abril/junho de 2019.

Disponível em: http://.seer.fundarte.rs.gov.br/index.php/RevistadaFundarte/index> 28 de junho de 2019. 